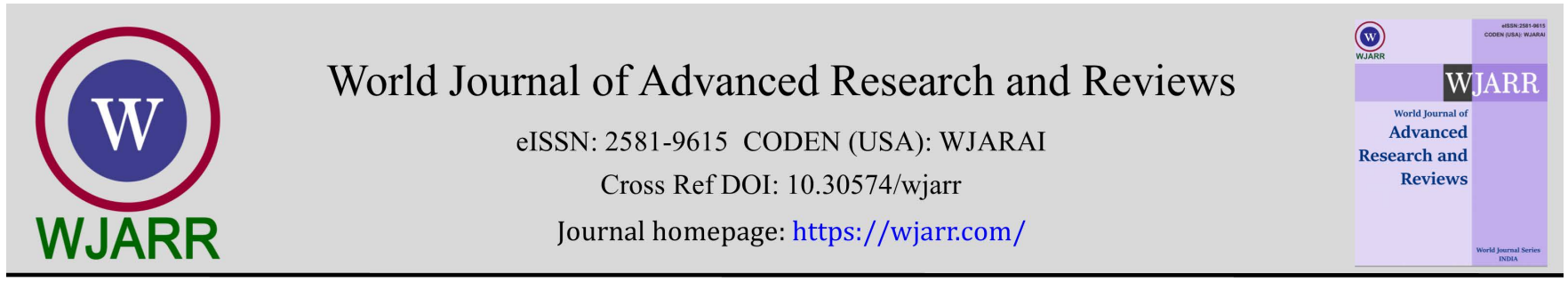

(RESEARCH ARTiClE)

Check for updates

\title{
Level of knowledge about handwashing and hand sanitizer at Taro village, Gianyar before and after counseling
}

\author{
Maftuhatur Rizkiyah Putri ${ }^{1}$, Almira Disya Salsabil ${ }^{1}$, I Made Agus Dwipayana ${ }^{1}$ and Widati Fatmaningrum ${ }^{2, *}$ \\ ${ }^{1}$ Faculty of Medicine, Universitas Airlangga, Surabaya, Indonesia. \\ ${ }^{2}$ Department of Public Health, Faculty of Medicine, Universitas Airlangga, Surabaya, Indonesia.
}

World Journal of Advanced Research and Reviews, 2022, 13(01), 250-254

Publication history: Received on 30 November 2021; revised on 04 January 2022; accepted on 06 January 2022

Article DOI: https://doi.org/10.30574/wjarr.2022.13.1.0766

\begin{abstract}
Introduction: The COVID-19 pandemic has harmed various fields, and people's activities cannot run as usual. Prevention of the transmission of COVID-19 is very important to be applied in everyday life. Washing hands with soap or hand sanitizer is easy and inexpensive prevention to do, but there are still many people who are wrong in practicing it. This needs to be done more counseling and education to the community in order to increase public knowledge about handwashing and hand sanitizer.
\end{abstract}

Method: This research is an analytic study with a research design using a one-group pretest-posttest design. Using 31 respondents from Taro villagers who attended the counseling. Data analysis using Paired Sample T-test and Kolmogorov-Smirnov Test for Normality Test.

Result: The average value of knowledge before counseling is 53.8710 while the value after counseling is 82.9677 . Paired Sample T-test and obtained a significance value of 0.000 so that a significant difference was found $(<0.005)$ between the values before and after counseling.

Conclusion: There is a significant difference in the level of knowledge before and after handwashing and hand sanitizer counseling.

Keywords: COVID-19; Handwashing; Hand sanitizer; Extension; Knowledge

\section{Introduction}

Corona Virus Disease - 2019 (COVID-19) was first discovered on December 31, 2019, in the city of Wuhan, China [1]. The spread of this new virus is so fast that it causes a global pandemic. In the latest WHO update, global new cases reached more than 3.4 million, and a death toll of nearly 57,000 deaths was reported (12-18 July 2021) [2]. In Indonesia, the first case of COVID-19 was found in March 2020 [3]. Until now there have been tens of thousands of cases and thousands of deaths [4]. In the latest update, the number of cases reached 2.95 million with the addition of more than 35,000 new cases every day [5].

Coronavirus is a zoonosis, so the possible origin of the spread is from animals to humans. The development of data shows transmission between humans (human to human). An analysis attempts to measure the rate of transmission based on the incubation period, symptoms, and duration between symptoms and isolated patients. The analysis states that transmission from 1 patient to 3 people in the vicinity, but there is still the possibility of 1 patient spreading more

\footnotetext{
${ }^{*}$ Corresponding author: Widati Fatmaningrum

Department of Public Health, Faculty of Medicine, Universitas Airlangga, Surabaya, Indonesia.

Copyright $(2022$ Author(s) retain the copyright of this article. This article is published under the terms of the Creative Commons Attribution Liscense 4.0.
} 
than that [6]. Based on existing data, comorbid hypertension and diabetes mellitus, male gender, and active smokers are risk factors for COVID-19 infection [7].

The most effective transmission of COVID-19 is through droplets/liquids that come out when coughing or sneezing and sticking to surrounding objects. The potential for spread is even greater in the community because people can be infected unknowingly anywhere and anytime. Most COVID-19 patients show symptoms in the respiratory system such as fever, cough, and shortness of breath [8]. More than $40 \%$ of fevers of COVID-19 patients have peak temperatures between $38.1-39^{\circ} \mathrm{C}, 34 \%$ exceed $39^{\circ} \mathrm{C}$, and the rest have no fever [9].

Hand washing has been recognized as an effective prevention method. This activity is an easy and inexpensive way to prevent the spread of disease [10,11]. Hands are often an intermediary for bacteria to enter the human body [12]. Washing hands has become a worldwide concern, this is because people still do not understand the practice of washing hands [13]. Burton's research in 2011 [14] proved that washing hands with soap was more effective than washing hands with water alone, soap can transfer germs. In addition to many people who do not know about the transmission of COVID-19, the community is also not yet orderly to carry out health protocols regarding the prevention of COVID-19 [15].

To reduce the spread of COVID-19, the community must implement health protocols [16]. Several precautions are recommended to avoid the spread of COVID-19: Wearing masks, washing hands, maintaining distance, staying away from crowds, and limiting mobility. The dynamics of the development of modern society, there are many innovative products, one of which is widely used by the community is hand sanitizer in the form of an antiseptic liquid or gel commonly called a hand sanitizer [17]. This practical and portable hand sanitizer makes it easier for the community and can help kill germs on the hands [18]. In addition, handwashing can reduce infection cases by up to 50\% [19].

The importance of maintaining hand hygiene is the background of researchers conducting counseling. In addition, there are still many people who do not understand how to wash their hands or use hand sanitizer properly. The increasing potential for the spread of disease is increasingly significant in the community around the community, which is the reason for education programs and handwashing practices to be prioritized [20]. Then the results of the extension need to be reviewed in order to see its effect on the level of community knowledge.

\section{Material and methods}

This research is quantitative. This type of research is analytic with the research design using a one-group pretestposttest design. In this study, a questionnaire (pretest) will be given at the beginning, then counseling will be carried out. To determine the effectiveness of the extension, the same questionnaire was administered at the end (posttest). The research is using 31 Respondents from Taro villagers who attended the counseling.

The counseling was carried out by playing a video containing education about handwashing and hand sanitizer, then explaining how to wash hands through videos and hands-on practice together. The last counseling was video screenings and workshops on how to make hand sanitizer with alcohol and aloe vera.

After the pretest and posttest data were collected, a normality test was carried out using the Kolmogorov-Smirnov Test and Statistical Analysis using the Paired Sample T-test to determine whether the scores before and after the counseling were significant or not.

\section{Results}

Table 1 Characteristic of Respondents

\begin{tabular}{|l|c|c|}
\hline \multicolumn{1}{|c|}{ Age Group } & Age Range & n (\%) \\
\hline Late teens & $17-25$ & $2(6.5 \%)$ \\
\hline Early adulthood & $26-35$ & $11(35.5 \%)$ \\
\hline Late adulthood & $36-45$ & $13(41.9 \%)$ \\
\hline Early elderly & $46-55$ & $5(16.1 \%)$ \\
\hline \multicolumn{2}{|c|}{ Total } & $31(100 \%)$ \\
\hline
\end{tabular}


Demographic age of the sample is grouped according to the classification of the Indonesian Ministry of Health. Based on table 1, most respondents are in the age range of 36-45 years (41,9\%), while the least respondents are in the age range of 17-26 years $(6,5 \%)$. Respondents had never received counseling and education regarding handwashing and hand sanitizer.

\subsection{Level of knowledge before and after attending counseling}

Table 2 Differences in knowledge levels before and after counseling

\begin{tabular}{|c|c|c|c|c|c|c|}
\hline & N & Minimum & Maximum & Mean & SD & p value \\
\hline Pretest & 31 & 33.00 & 78.00 & 53.8710 & 12.15934 & \multirow{2}{*}{$<0.001$} \\
\hline Posttest & 31 & 56.00 & 100.00 & 82.9677 & 11.99579 & \\
\hline
\end{tabular}

The results showed that before attending the counseling, the highest pretest score was 78.00 and the lowest score was 33.00. The mean value of the pretest is 53.8710 . As many as 11 people (35.5\%) had a pretest score below the average and 20 people (64.5\%) had a pretest score above the average. After attending the counseling, the highest posttest score was 100.00 and the lowest posttest score was 56.00 . The average posttest score is 82.9677 . A total of 17 people (54.8\%) had a posttest score below the average and 14 people $(45.2 \%)$ had a posttest score above the average.

In the data on the level of knowledge before and after counseling, a normal data distribution (0.078 $>0.05)$ was used, then the Paired Sample T-test was used and a significance value of $<0.001$ was found so that a significant difference $(<0.05)$ was found between the values before and after administration counseling.

\section{Discussion}

Researchers conducted counseling by playing videos, the direct practice of handwashing steps, and workshops on how to make hand sanitizer. Materials provided through health education are usually able to change a person's behavior from not knowing to know [21]. After counseling, it is also hoped that the community can disseminate information to others in handling the prevention of COVID-19 transmission [22].

Before the counseling regarding handwashing and hand sanitizer, based on the respondent's pretest the mean value was 53.8710. After attending the counseling, the posttest means value increased to 82.9677. Similar to previous research, knowledge before counseling is still very low so it is necessary to conduct counseling and direct practice to increase respondents' knowledge [23]. It is proven that counseling can increase people's knowledge. Even though in the posttest there were still people who got scores below the average, but all respondents got an increase in scores from before and after the counseling. According to research conducted in 2019, there was a significant difference in the level of knowledge before counseling [24].

In addition to playing educational videos, we also practice handwashing steps directly. Because based on the results of the questionnaire, there are still many people who ignore the length of time to wash their hands using soap or hand sanitizer, people are still in a hurry and don't do the right steps. The duration of handwashing according to WHO standards are 20-30 seconds if using a hand sanitizer and 40-60 seconds if using soap and running water. This can reduce colony formation thereby reducing the number of germs/viruses [25].

In the guidance of making Hand sanitizer, people still find it difficult to determine the number of ingredients. Minimum alcohol is $60 \%$ in a mixture, therefore the amount in each ingredient must be measured accurately. To make it easier, researchers have also provided measuring cups to make it easier for the public. Hand sanitizer containing alcohol can also be an option because of its practical nature and can kill germs/viruses that stick to the hands [26].

Health counseling in the form of education and counseling can increase knowledge, this is because in the extension process it is accompanied by demonstrations and direct practice so that people can easily grasp the material. This research has an impact on the knowledge of each individual and can change the behavior of washing hands with the right soap/hand sanitizer. In addition, the community can distribute knowledge and invite the surrounding environment to wash their hands so that the sanitation of the surrounding environment becomes better. 


\section{Conclusion}

Based on the results and discussion that there is an influence in the counseling activities of handwashing and hand sanitizer. This illustrates an increase in the average from before and after the counseling. It is hoped that the community can also change their behavior to be healthier by washing their hands properly because washing their hands with the right steps can reduce the spread and transmission of COVID-19.

\section{Compliance with ethical standards}

\section{Acknowledgments}

The authors would like to thank Taro Village's stake holders and residents and Faculty of Medicine, Universitas Airlangga, Surabaya, Indonesia for supporting this study.

\section{Disclosure of conflict of interest}

The authors declare that there is no conflict of interest that would affect the findings of this study.

\section{Statement of informed consent}

Informed consent was obtained from all participants included in this study.

\section{References}

[1] Lee A. Wuhan novel coronavirus (COVID-19): why global control is challenging. Journal of Public Health. January 2020; 19-21.

[2] World Health Organization. COVID-19 Weekly Epidemiological Update on COVID-19. 2021, July 20. [cited 21 July 2021]. Available from https://www.who.int/publications/m/item/weekly-epidemiological-update-on-covid19---20-july-2021.

[3] Rahmadani W, Sihombing SC. Analysis of the Spread of the COVID-19 Virus in South Sumatra Province Using the Lagrange Interpolation Method. Journal of Physics and Its Applied Research. 2020; 2(1):12-23.

[4] Özdin S, Bayrak Özdin Ş. Levels and predictors of anxiety, depression and health anxiety during COVID-19 pandemic in Turkish society: The importance of gender. International Journal of Social Psychiatry. 2020 Aug;66(5):504-511.

[5] Indonesia's COVID-19 Handling Task Force. Indonesia Distribution Data of COVID-19. 2021, July 20. [cited 2021 July 2021]. Available from https://covid19.go.id/situasi.

[6] Handayani D, Hadi DR, Isbaniah F, Burhan E, Agustin H. Corona Virus Disease 2019. Jakarta Timur: Journal Respirology Indonesia. 2020;2(2):119-120.

[7] Susilo A, Rumende CM, Pitoyo CW, Santoso WD, Yulianti MM, Herikurniawan H, Sinto R, Singh G, Nainggilan L, Nelwan EJ, Chen LK, Widhani A, Wijaya E, Wicaksana B, Maksum M, Annisa F, Jasirwan CoM, Yunihastuti E. 2020. Coronavirus Disease 2019: Recent Literature Review. Indonesian Journal of Internal Medicine. 2020;7(1):45-67.

[8] Rothan HA, Byrareddy SN. The epidemiology and pathogenesis of coronavirus disease (COVID-19) outbreak. J Autoimmun. Journal of Autoimmunity. 2020;109(102433):1-4.

[9] Huang C, Wang Y, Li X, Ren L, Zhao J, Hu Y, Zhang L, Fan G, Xu J, Gu X, Cheng Z, Yu T, Xia J, Wei Y, Wu W, Xie X, Yin W, Li H, Liu M, Xiao Y, Gao H, Guo L, Xie J, Wang G, Jiang R, Gao Z, Jin Q, Wang J, Cao B. (2020). Clinical features of patients infected with 2019 novel coronavirus in Wuhan, China. Lancet. 15 Feb 2020; 395(10223): $497-506$.

[10] Desiyanto FA, Djannah SN. Effectiveness of Hand Washing Using Antiseptic Hand Sanitizer (Hand Sanitizer) Against the Number of Germs. Journal of Public Health. 2013; 7(2): 75-82.

[11] Dajaan DS, Addo HO, Ojo L, Amegah KE, Loveland F, Bechala BD, Benjamin BB. Hand washing knowledge and practices among public primary schools in the Kintampo Municipality of Ghana. International Journal of Community Medicine and Public Health. 2018; 5(6): 2205.

[12] Risnawaty G. Determinant Factors of Handwashing Behavior with Soap in Communities in Kalikewall. Journal PROMKES. 2017; 4(1): 70-81. 
[13] Wikurendra A. The Effect of Handwashing with Soap Counseling on Students' Handwashing Attitudes, Journal Scientific Media Husada. 2018; 7(2): 64-69.

[14] Burton MC. The effect of hand washing with water or soap on bacterial contamination of hands. Int. J. Environ. Res. Public Health. 2011; 8(1): 97 - 104.

[15] Duan L, Shao X, Wang Y, Huang Y, Miao J, Yang X, Zhu G. An investigation of mental health status of children and adolescents in china during the outbreak of COVID-19. Journal of Affective Disorders. 2020; 275: $112-118$.

[16] Gasmi A, Noor S, Tippairote T, Dadar M, Menzel A, Bjørklund G. Individual risk management strategy and potential therapeutic options for the COVID-19 pandemic. Clinical Immunology. 2020; 215: 108409.

[17] Suswati I, Maulida AP. Handwashing promotion and the use of hand sanitizer as a preventative measure on the development of bacteria. Journal of Community Service and Empowerment. 2020; 1(1): 31-36.

[18] Susilaningrum DF, Ujilestari T, Ariani P, Salsabila S, Hidayah KN. Hand Hygiene: Hand Washing vs. Hand Sanitizer for Killing the Germs. Indonesia Journal of Biology Education. 2021; 4(1):19-24.

[19] Mustikawati IS. Handwashing Behavior with Soap Qualitative Study on Mothers in Muara Angke Fisherman's Village, North Jakarta. ARKERMAS. 2017; 2(1): 115 - 125.

[20] Pratiwi WR, Hamdiyah, Asnuddin. Early Detection of Reproductive Health Problems Through Adolescent Health Posts. Journal Innovation Results of Community Service. 2020; 3(1): 87-94.

[21] Zhang M, Zhou M, Tang F, Wang Y, Nie H, Zhang L, You G. (2020). Knowledge, attitude, and practice regarding COVID-19 among healthcare workers in Henan, China. Journal of Hospital Infection. 2020; 105(2): $183-187$.

[22] Herron J, Hay-David A, Gilliam AD, Brennan PA. Personal Protective Equipment and Covid 19- A Risk to Healthcare Staff. The British Journal of Oral \& Maxillofacial Surgery. 2020; 58(5): 500-502.

[23] Astuti Y, Fandizal M, Sani DN, Safari U, Elviana N, Riani N, Irsan. Fight Covid-19 by Making Hand Sanitizer and Strengthening Hand Washing. Advanced Indonesian Community Service Journal. 2020; 01(03):73-76.

[24] Yanti M, Alkafi, Bustami. Differences in Knowledge Levels and Attitudes towards Handwashing with Soap Counseling for Elementary School Students. Journal of Health Sciences. 2019; 3(2): 80-84.

[25] Ta'adi, Setiyorini E, Amaliya MR. Factors Associated with Handwashing Compliance 6 Steps the First Moment in the Patient's Family in the Children's Room. Journal Ners and Midwife. 2019;6(2):203-210.

[26] Lusiana RA, Widodo DS, Syanti L, Gunawan, Haris A. Education on the Making of Aloe Vera-Based Hand Sanitizer for the Community of Harjowinangun Village, Grobgan. Tabikpun Community Service Journal. 2020;1(1):47-55. 